\title{
ランドサット TM データによる土地被覆変化の抽出に関する研究 EXTRACTION OF LAND COVERING CHANGES BY LANDSAT TM DATA
}

\author{
斉藤郁雄*, 朴明 浩**, 石原修*** \\ Ikuo SAITO, Minghao PIAO and Osamu ISHIHARA
}

\begin{abstract}
When a secular change of land covering is examined by using remote sensing data, a degree of solar radiation in the observation day and a difference in the growth conditions of the plant cause a trouble. In this paper, the method of getting rid of the influence that occurs by the difference in the weather condition is proposed, and a secular change of NVI(Normalized Vegetation Index) is examined. Furthermore, the new index NUI (Normalized Urban Index) to distinguish green covering and non-green covering without influences of solar radiation and the growth conditions of the plant is proposed. Secular changes in land covering of Kumamoto City is made clear by using NUI.
\end{abstract}

\author{
Keywords: Land covering distribution, Secular changes, Landsat TM data, Normalized vegetation index, \\ Normalized urban index \\ 土地被覆分布, 経年変化, ランドサット TMデータ, NV I, N U I
}

\section{1.はじめに}

人工衛星ランドサットに搭載されたTM（Thematic Mapper）セ ンサは可視 3 バンドの他に近赤外 1 、中赤外 2 、遠赤外 1 バンドを 観測しており、解像度も $28.5 \mathrm{~m}$ （遠赤外のみ $120 \mathrm{~m}$ ） と比較的高いた め、これまで都市域のさまざまな環境解析に用いられてきた ${ }^{1) \sim 5) 。 ~}$ また、TMセンサは 1982 年 7 月に打ち上げられたランドサット 4 号以降、現在使用されている 7 号（センサはE TM+）まで約 20 年に亘るデータの蓄積があるため、都市環境の長期モニタリングの 一手法として今後も様々な分野での活用が可能であると考えられる。 従来、リモートセンシングデータを用いて土地被覆の変化を求め る方法としては、NVI (Normalized Vegetation Index) などを 用いて各年度のスペクトルを直接比較する方法6）7）や年度毎に土 地被覆分類を行い、その結果を比較する方法 ${ }^{8)}$ などが提案されて いる。しかし、土地被覆変化を求める場合、以下の 2 つの問題点が あり、解析精度の面で十分な結果が得られるとは限らない9)。 (1)観測日によって放射照度が異なる。

(2)観測日、特に季節によって緑の生育具合が異なる。 本研究は、リモートセンシングデータを用いて都市域における土 地被覆変化を継続的に長期に亘ってモニタリングすることを前提と しており、特に土地開発や都市緑化等に伴う緑被変化を客観的・定 量的に抽出する方法の確立を目的としている。

* 八代工業高等尃門学校士林建築工学科 教授・博士 (工学)

** 熊本大学大学院自然科学研究科 大学院生

*** 熊本大学工学部環境システム工学科 教授・工博
本報告では、まずデータ数の確保のしやすさについて検討するた めにランドサットTMデータの観測状況について調べている（第 2 章）。次に、気象条件の違いによって生じる放射照度等の影響の除 去方法について提案する（第 3 章）とともに、正規化植生指標 N V I による経年変化抽出の問題点について検討している（第 4 章）。 また、放射照度や緑の生育具合の影響を除去した上で、緑被と非緑 被を判別するための新しい指標N U I (Normalized Urban Index) を提案し、土地開発などに伴う土地被覆変化の抽出の可能性につい て検討している（第 5 章）。

\section{2.土地被覆変化抽出のためのデータ数確保の可能性について}

人工衛星ランドサットは地球を 16 日周期で周回している。従っ て、同じ地域の観測回数は年間 20 回程度である。図ー 1 は 1984 年 から 1998 年の約 15 年間に観測された 4 地域（九州 : パス 112, ロ ウ 37,236 シーン, 関東 : パス 107, ロウ 35,272 シーン, 北海道 : パス 107, ロウ 30,272 シーン, 関西 : パス 110 , ロウ 36,246 シー ン）における雲量別の観測頻度である。各地域とも観測時の雲量が 0 である頻度は $5 \%$ 以下であり、雲量 2 まで含めても全体の 1 割を 超える程度である。解析対象エリアの大きさにもよるが、使用可能 な観測データは年間に数シーンであることが分かる。 rof., Dept. of Civil Eng. and Architecture, Yatsushiro National College of Technology, Dr. Eng. Graduate Student, Graduate School of Science and Technology, Kumamoto University

Prof., Dept. of Architecture and Civil Eng., Fac. of Eng. Kumamoto University, Dr. Eng. 
土地被覆の経年変化を抽出するためには季節に伴う緑の生育状況 が同じであることが望ましい。図ー 2 は観測時の雲量が 2 以下の場 合を月別に集計した結果であるが、各地域とも夏場の雲量が大きく、 雲の無い画像が得やすいのは 3 月から 4 月であることが分かる。従 って土地被覆変化を定期的に継続して調べたい場合、3月から 4 月 を中心に収集する方がデータ数が確保しやすいと考えられる。

\section{3、気象条件に伴う放射照度等の影響の除去}

\section{1 覞測年度に伴うヒストグラムの变化}

表ー 1 に、本章で使用したTMデータの観測概要と観測日の気象 条件を示す。季節の違いによる緑の生育状況の違いの影響を小さく するために 4 月の終わりから 5 月の始めにかけてのデータを使用し ている。ただし、各年度の画像データは、相対的な比較を容易にす るために、1985 年の画像座標に合わせて幾何補正を行っている。

図ー3は各バンドのヒストグラムを年度別に比較したものである。 各バンドとも年度により分布傾向が異なっている。従来、このよう な異なる年度の画像データから土地被覆変化を求める場合、各年度 毎に土地被覆分類等を行いその比較を行うことが多かった。しかし、 土地被覆分頑に用いる教師データは各年度の放射照度や緑の生育状 況の違いに伴ってシーン毎に抽出・解析する必要があり、年度に伴 う土地被覆変化を客観的・定量的に評価することは困難であった。

\section{2 リモートセンシングにより钼測される放射輝度}

リモートセンシング観測においてセンサーに入射する電磁波（遠 赤外域を除く）のエネルギーLは、一般に次式で与えられる。

$$
L=\tau E \rho+R
$$

ただし、 L : センサーに入射する分光放射輝度

$\tau$ : 反射光の大気中における透過率

E：地表面における分光放射照度

$\rho:$ 地表面の分光反射率

$\mathrm{R}$ : パスラディアンス

ここで、大気の透過率 $\tau 、$ 分光放射照度 $\mathrm{E} 、$ パスラディアンス $\mathrm{R}$ が等しければ同一被覆物の放射輝度 Lは等しいと考えられる。特に、 水面や人工被覆物の表面反射率 $\rho$ は季節や年度に伴う変化が小さく、 $\mathrm{L}$ の変化は主に分光放射照度 $\mathrm{E}$ 等の気象条件の違いが反映されるも

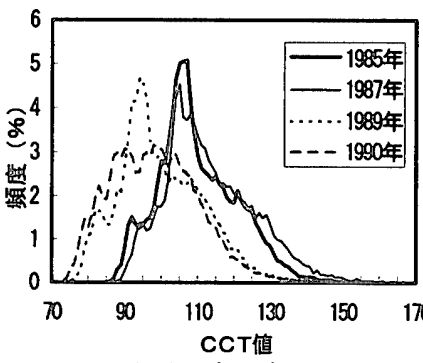

(a) バンド 1

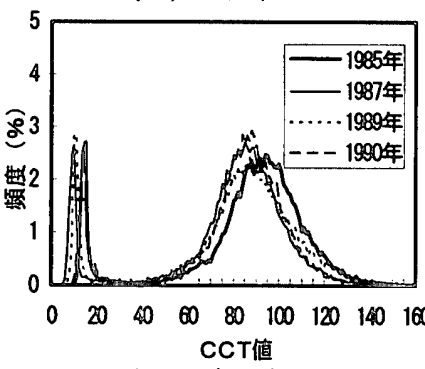

(๑) バンド5

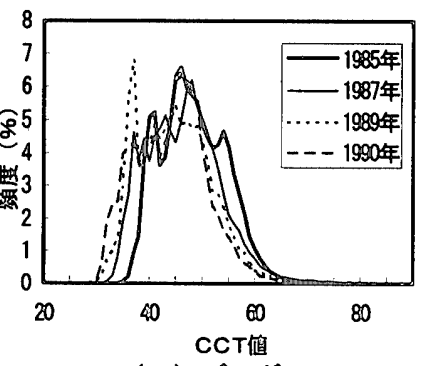

(b) バンド2

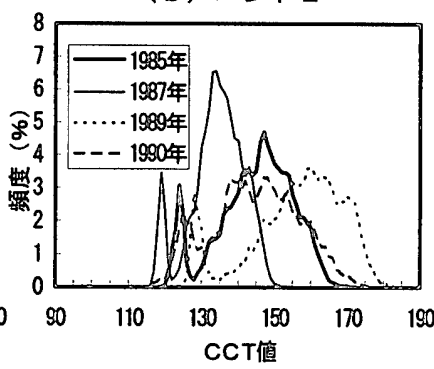

(8）バンド6

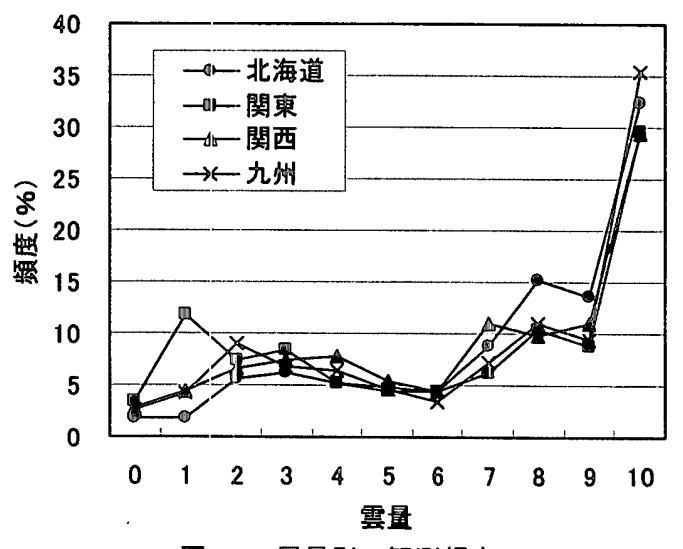

图ー 1 毁置別の観測頻度

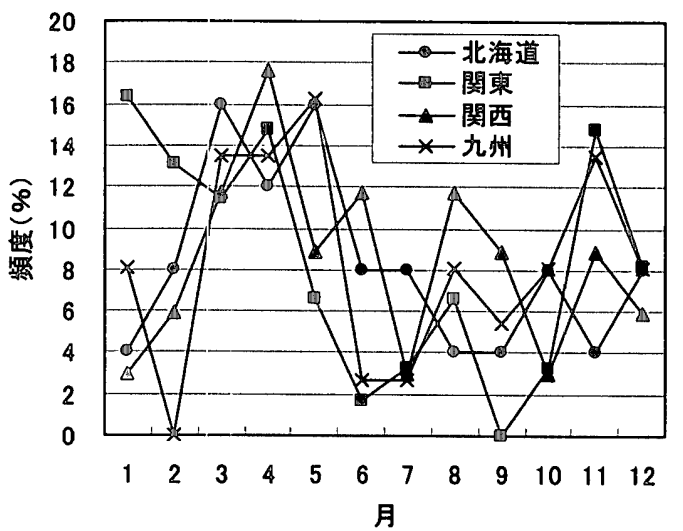

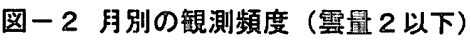

表ー1 TMデータの観測概要及び観測日の気象条件

\begin{tabular}{|c|c|c|c|c|c|c|c|}
\hline 観 & \multicolumn{2}{|c|}{ 測 } & 年 & 1985 年 & 1987 年 & 1989 年 & \multirow{2}{*}{$\frac{1990 \text { 年 }}{5 \text { 月 } 16 \text { 足 }}$} \\
\hline 観 & 測 & 月 & 日 & 5月 2 日 & 5 月 8日 & 4月 27 日 & \\
\hline 観 & 測 & 時 & 刻 & $10: 17$ & $10: 17$ & $10: 17$ & $10: 17$ \\
\hline \multirow{5}{*}{$\begin{array}{l}\text { 観測 } \\
\text { 日の } \\
\text { 天候 }\end{array}$} & \multicolumn{3}{|c|}{ 日平均気温 $\left({ }^{\circ} \mathrm{C}\right)$} & 20.5 & 18.5 & 18.1 & 20.8 \\
\hline & \multicolumn{3}{|c|}{ 日平均雲量 $(1 / 10)$} & 0.0 & 1.0 & 0.8 & 9.5 \\
\hline & \multicolumn{3}{|c|}{ 降水量 $(\mathrm{mm})$} & 0.0 & 0.0 & 0.0 & 0.0 \\
\hline & \multicolumn{3}{|c|}{ B照時間 (h) } & 11.3 & 12.2 & 11.0 & 5.5 \\
\hline & \multicolumn{3}{|c|}{06 時-18 時天気 } & 晴れ & 晴れ & 快晴 & 晴後舅 \\
\hline
\end{tabular}

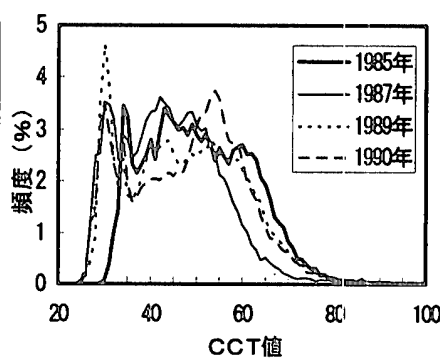

(c) パンド3

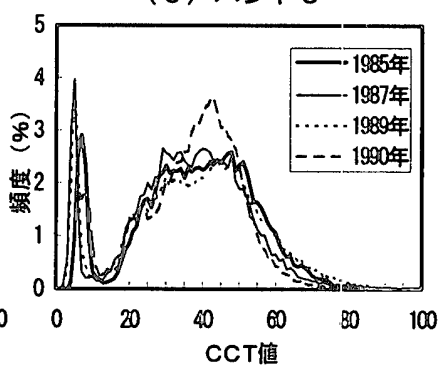

(g) バンド7

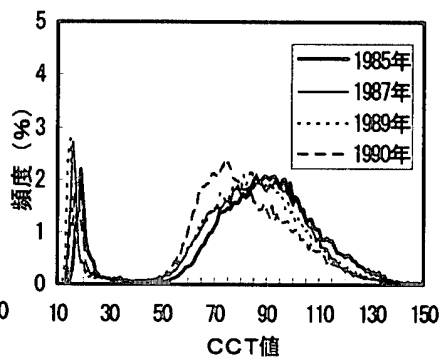

(d) バンド4
图ー3 各年度のヒストグラムの比較 
のと考えられる。一方、緑の反射率 $\rho$ は生育状況によって変化する。 水面および人工被覆物のように表面反射率 $\rho$ が季節や年度に伴っ て変化しないと考えた場合、シーン $\mathrm{a}$ とシーン $\mathrm{b}$ で観測される放射 輝度 $\mathrm{L}$ 、およびL。は次式で表される。

$$
\left\{\begin{array}{l}
L_{a}=\tau_{a} E_{a} \rho+R_{a} \\
L_{b}=\tau_{b} E_{b} \rho+R_{b}
\end{array}\right.
$$

ただし、 $\tau a, \tau b: シ-ン a 、 b$ 観測時の大気の透過率

$\mathrm{E} a, \mathrm{~Eb}: \dot{\forall}-$ $\mathrm{a} 、 \mathrm{~b}$ 観測時の分光放射照度

$\mathrm{R} a, \mathrm{R} b$ : ジー $\mathrm{a} 、 \mathrm{~b}$ 観測時のパスラディアンス

式(2)より $\mathrm{L}_{\mathrm{a}}$ と $\mathrm{L}_{\mathrm{b}}$ の関係は次のような 1 次式で表される。

$$
L_{a}=A L_{b}+B
$$

ここで、

$$
A=\frac{\tau_{a} E_{a}}{\tau_{b} E_{b}} \quad \text { また } B=R_{a}-\frac{\tau_{a} E_{a}}{\tau_{b} E_{b}} R_{b}
$$

従って水面および人工被覆物のエリアの放射輝度 $\mathrm{L}_{\mathrm{a}}$ および $\mathrm{L}$ 。 の関係を調べることにより、式(3)を用いて気象条件の違いによる 放射照度等の影響を除去することが可能であると考えられる。

\section{3 放射照度等の影響の除去}

式（3）に基づいて、土地被覆分類により抽出した水面および人工 被覆物における各バンドの累積度数 $5 \%$ 值と $95 \%$ 值により放射照 度等の影響を除去する方法について検討する。

まず、1985 年の画像を基にユークリッド距離法を用いた土地被 覆分類により水面、樹木、田畑・草地、裸地、人工被覆物の 5 項目 に分類する。次に水面および人工被覆物に分類された全ピクセル

（画像全体の 19.2\%）における各年度の各バンドの累積度数から $5 \%$ 值と $95 \%$ 值を求めている。1985 年と 1987 年における各バンド の累積度数 $5 \%$ 値と $95 \%$ 値の関倸を図ー 4 に示す。ただし、図 -4

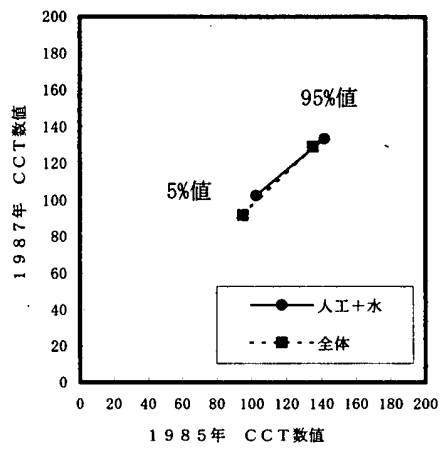

(a) パンド 1

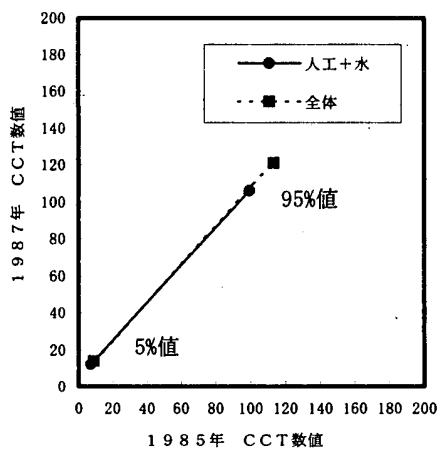

(日) バンド5

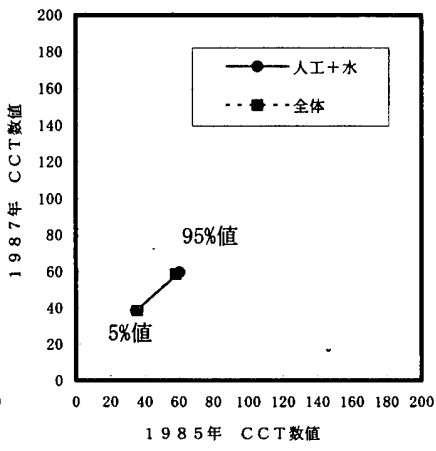

(b) ハンンド 2

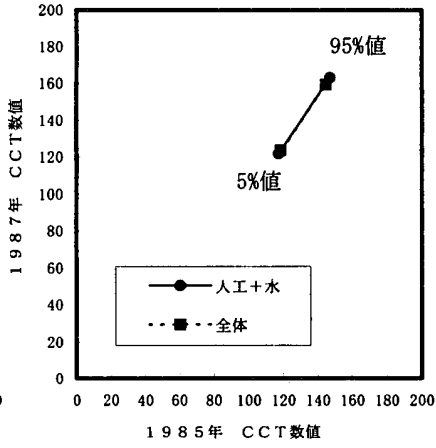

(f) ハンド6

には各年度の画像全体から抽出した累積度数 5\%值と $95 \%$ 值の関係 も合わせて示している。

図ー4において、バンド 4 を除く他のバンドでは水面および人工 被覆物から抽出した $5 \%$ 値と $95 \%$ 值の関係は全体から抽出した $5 \%$ 值と $95 \%$ 值の関倸とほぼ致している。しかし、バンド 4 では水 面および人工被覆物から抽出した $95 \%$ 值と全体から抽出した $95 \%$ 值が大きく異なっており、5\%值と $95 \%$ 值を結ぶ直線の傾きも異な っている。バンド 4 は植生の活性度を反映するバンドであり、水面 および人工被覆物のエリアから抽出した $5 \%$ 值、95\%值に基づいて 式（3）で補正する方法を樹木や田畑などに適用した場合、誤差が大 きくなるものと考えられる。

そこで、画像全体から抽出した各バンドの累積度数 5\%值と $95 \%$ 值の関係に基づいて、式(3)により気象条件に伴う放射照度等の影 響の除去を行うことにする。ただし、各年度の画像は 1985 年度の 画像に規準化するものとして表一 2 に示す係数を用いる。また、式 （3）は、本来可視域や近中赤外域について成り立つと考えられるが、 バンド 6 (遠赤外域）についても同様に適用して検討している。

前節での方法により放射照度等の影響の除去を行い、1985 年の 画像に規準化した結果を図ー 5 に示す。補正前の図ー 3 と比べると 各年度の頻度分布が一致していることが分かる。

表-2 放射照度等の影響の除去のための変換式 (3) の係数

\begin{tabular}{c|c|r|r|r|r|r}
\hline \multirow{2}{*}{} & \multicolumn{2}{|c|}{1987 年 $\rightarrow 1985$ 年 } & \multicolumn{1}{|c|}{1989 年 $\rightarrow 1985$ 年 } & \multicolumn{1}{|c|}{1990 年 $\rightarrow 1985$ 年 } \\
\cline { 2 - 7 } & $\mathrm{A}$ & $\mathrm{B}$ & $\mathrm{A}$ & $\mathrm{B}$ & $\mathrm{A}$ & \multicolumn{1}{c}{$\mathrm{B}$} \\
\hline バンド 1 & 0.919 & 4.824 & 0.928 & 16.294 & 0.961 & 15.385 \\
\hline バンド2 & 0.893 & 6.687 & 0.886 & 8.117 & 0.910 & 8.568 \\
\hline バンド3 & 1.075 & 3.192 & 0.862 & 8.465 & 0.932 & 6.735 \\
\hline バンド4 & 1.036 & 2.340 & 1.014 & 3.796 & 1.056 & 0.541 \\
\hline バンド5 & 1.023 & 4.898 & 0.968 & 3.935 & 1.108 & -1.384 \\
\hline バンド6 & 1.360 & -37.606 & 0.798 & 21.284 & 0.898 & 12.379 \\
\hline バンド7 & 1.016 & 2.032 & 0.904 & 1.963 & 1.152 & -1.762 \\
\hline
\end{tabular}

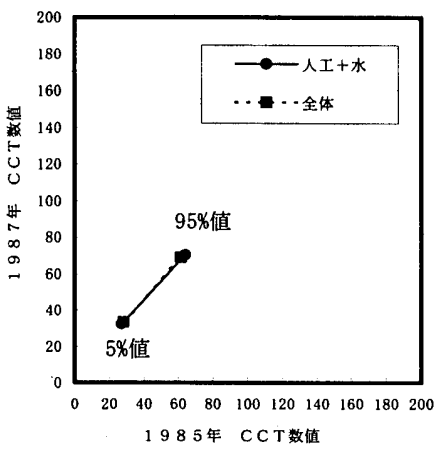

(c) バンド 3

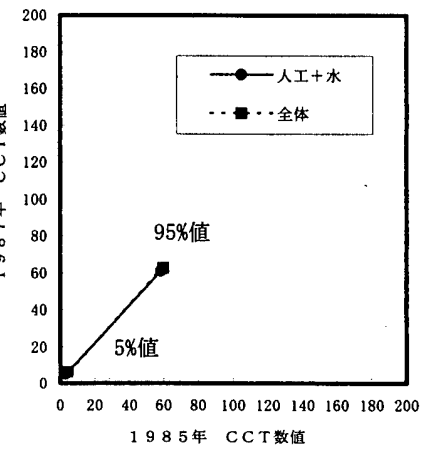

(g)バンド7

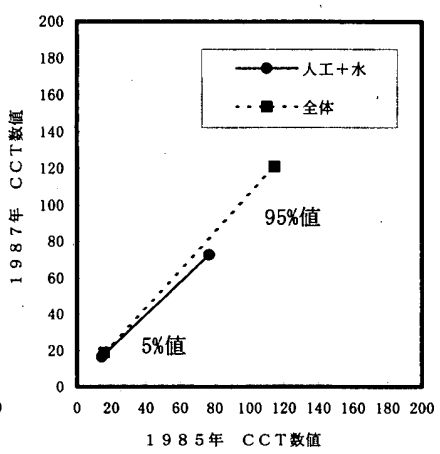

(d) バンド 4

図ー4 1985 年と 1987 年の各バンド の累皘度数 $5 \%$ 值と $95 \%$ 值 の関係 


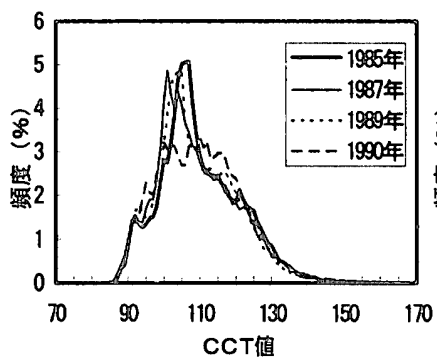

(a) バンド 1

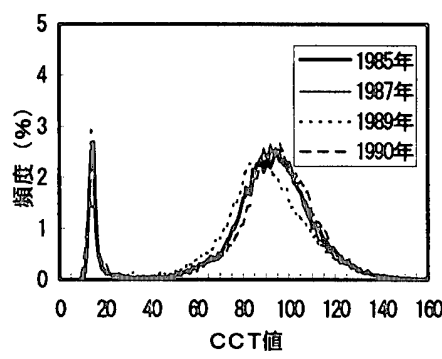

(e) パンド5

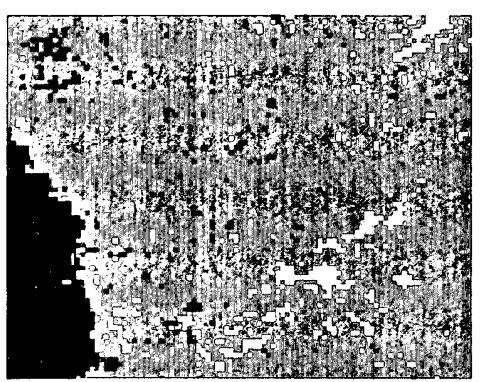

（a） 1985 年 $\rightarrow 1987$ 年

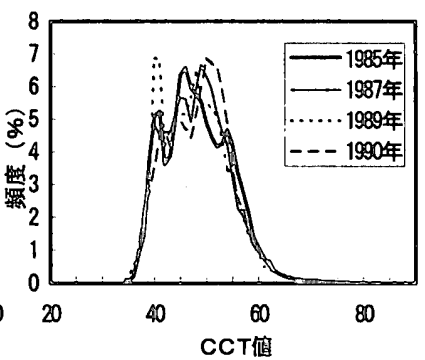

(b) パンド2

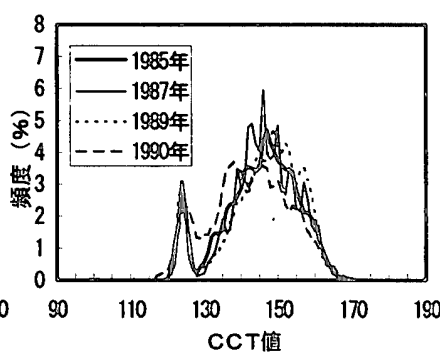

(f）バンド 6

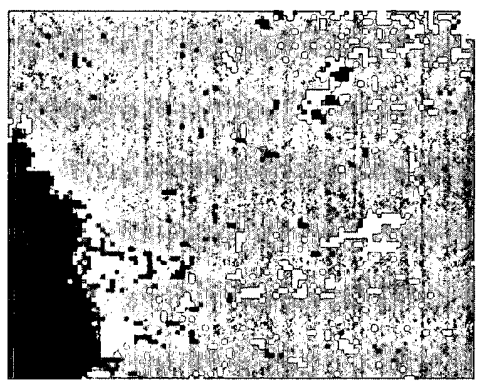

（b） 1985 年 $\rightarrow 1989$ 年

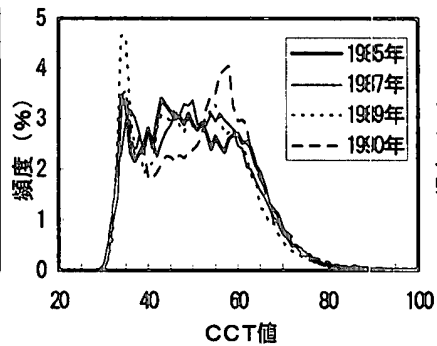

(c) パンド 3

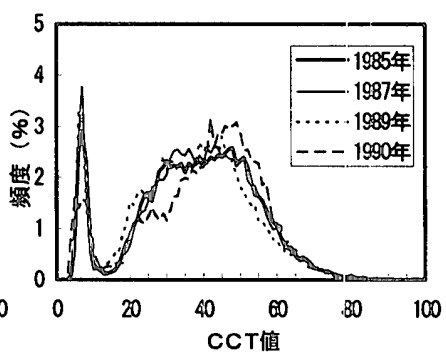

(g) パンド7

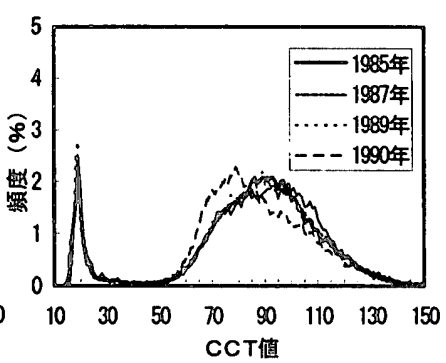

(d) パンド 4

图一5 放射照度等の影䣷除去後の各年 度のヒストグラムの比較

図ー6 1985 年から 1990 年にかけてのN V I の差画像

4.NVIによる土地被覆变化の抽出

前章で提案した方法により放射照度の影響の除去を行い 1985 年 の画像に規準化した各年度のバンド $3\left(B A N D 3^{*}\right)$ とバンド 4

$\left(B A N D 4^{\circ}\right)$ のデータを使用して次式により NV I を算出している。

$$
N V I=\frac{B A N D 4^{\circ}-B A N D 3^{\circ}}{B A N D 3^{*}+B A N D 4^{\circ}} \times 100+100
$$

ただし、1989 年と 1990 年の画像には雲および雲の影が見られた ため、下記の判断基準に基づいて水面、雲および雲の影をあらかじ め除去している。

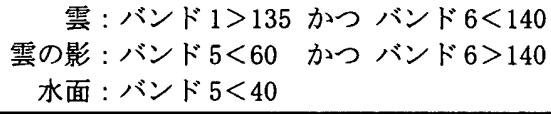

図ー6に 1985 年と各年度のN V I の差画像を示す。ここで、N VI の差が負の值を示す地域は緑の活性度が低下した地域、すなわ ち、土地開発が進み緑が人工被覆物に変化した地域や田畑において 緑から裸地等へ変化した地域である。

図ー6によると、いずれも市街地の周辺部、特に南部から東部に おいてNVIが低下していることが分かる。また、表一3に示すよ うに熊本市全域で見た場合、NVIの低下している割合が年度に伴 って大きくなっている。

ただし、図ー6 (c)に示すように 1985 年から 1990 年にかけては 熊本市南部でN V I が大きく低下している。これは、1990 年の観
表一3 熊本市全域におけるNVIの变化の割合（\%)

\begin{tabular}{l|c|c|c|c|c|c}
\hline & $\begin{array}{c}\text { 水面 } \\
\text { 雲 }\end{array}$ & $\begin{array}{c}20 \text { 以上 } \\
\text { 増加 }\end{array}$ & $\begin{array}{c}10 \sim 20 \\
\text { 増加 }\end{array}$ & $\begin{array}{c}\text { 増减 } \\
\text { なし }\end{array}$ & $\begin{array}{c}10 \sim 20 \\
\text { 減少 }\end{array}$ & $\begin{array}{c}20 \text { 以上 } \\
\text { 減少 }\end{array}$ \\
\hline $1985 \rightarrow 1987$ 年 & 11.34 & 0.75 & 5.45 & 75.07 & 5.95 & 1.44 \\
\hline $1985 \rightarrow 1989$ 年 & 13.32 & 1.13 & 5.99 & 71.20 & 6.72 & 1.64 \\
\hline $1985 \rightarrow 1990$ 年 & 11.37 & 0.62 & 6.20 & 61.10 & 12.96 & 7.75 \\
\hline
\end{tabular}

測日が他の観測日に比バて一番遅い時期であり、田植えに伴って田 烟に水が張られたこと汸原因であると考えられ、土地開発による土 地被覆変化との区別は目難である。

\section{5. 正規化都市指標NU I}

前章までの結果より放射照度の影響を除去した上で、NVI を比較する方 法は土地被覆の変化状况を把握するための一つの方法であると考えられる。 しかし、先に述べたように土地開発等に伴う土地被覆の経年変化を把握した い場合、NVI は緑の生雬具合の影響を受けることになり、客観的・定量的 な評価は困難である。そ:で、本章では、緑被と非緑被をより客観的に 評価し、その経年変化を抽出する手法について検討を行う。

表ー4は本章での解析に使用したランドサットTMデータの観測概要であ る。シーン数を増やすとともに季節による緑の生育状况の影響を比較するた めに新たに9月のデータ（シーン6）も加えている。

\subsection{NVIのヒストグラムの経年変化}

図一7に 1985 年から 1997 年の各シーンにおけるNV I の累積度数分布を 示す。ただし、凡例のカッコ内はNVI の平均值である。NVIはバント間 
の比演算処理の1つであるので、勧測日時の放射照度の影響はある程度除去 できると考えられるが、1990 年 9 月や 1997 年 4 月の值が大きくなっている。 熊本市周辺の水田では、4月の終わり頃から田植えの準備のために田おこし や水張りが始まり 5 月の終わり頃からの田植えの後 10 月に稻刈りが行われ る。そのため、5月の水田は 4月や9月に比へて植生の活性度低く、観測日 による植生の生育状況の違が分布傾向に現れているものと考えられる。また、 NVI の度数分布は正規分布に近く分散も小さいため、これを元に、緑被と 非緑被を判別しようとしても闌值の設定が難しいことが分かる。

\section{2 正規化都市指標NU I}

樹木や田畑などの緑被と市街地や裸地などの非緑被における各バンドのC CT值は一般に表一 5 のような傾向を示寸と考えられる。そこで、緑被と非 緑被の判別を目的として次式で示す正規化都市指標NU I （Normalized Urban Index）を提案する。式(5)は表一5の関係より非緑被は緑被に比べて バンド3、6では值が大きくなり、バンド4，5では值が小さくなるものと 考え、その傾向を総合的に表すために定義した式である。

$$
\begin{aligned}
N U I= & \overline{B A N D 3}+\overline{B A N D 6} \\
& -\overline{B A N D 4}-\overline{B A N D 5}
\end{aligned}
$$

ただし、 $\overline{B A N D 3} \cdots \overline{B A N D 4}$ は式(6)により正規化した各バンドの值 である。

$$
\begin{gathered}
\overline{B A N D n}=\frac{B A N D n-A V E_{B A N D n}}{S D_{B A N D n}} \times 50+100 \\
\text { ただし、 } B A N D n \quad: \text { バンドnのCCT值 } \\
A V E_{B A N D n}: \text { バンドnの平均 } \\
S D_{B A N D n}: \text { バンドnの標準偏差 }
\end{gathered}
$$

図一8は各シーンにおけるNU I の累積度数分布である。図一 7 と比較 すると観測日の違いによる分布傾向の差は小さく、観測日の季節が異なる 1990 年 9 月についても他のシーンとほほ同様の傾向を示している。また、分 布が均一で分散が大きいため緑被と非緑被の閾值の設定が容易であり、各シ ーンに共通の閥值を設定しても判別結果に大きな差は出ないことが分かる。

\section{3 NUIによる熊本市の土地被輹変化の抽出}

前節の結果を元に、熊本市における土地被覆の経年変化について調べる。 ただし、緑被と非緑被の判別基淮は現地調查や住宅地図などのグランドトル ースデータを基に以下のように設定している。

$$
\begin{aligned}
& \text { 緑 被: NU I }<200 \\
& \text { 非緑被: NU I } \geqq 200
\end{aligned}
$$

図ー9に各シーンの判別結果を示す。各シーンともほほ司様の結果となっ ており、年度による増堿は多少あるもののその差は $5 \%$ 以内である。シーン 6 (1996 年 9 月) やシーン7 (1997 年 4 月) なと緑の生育状况の異なるシ 一ンの判別結果も含めて、特に大きな違いは見られない。全シーンを同じ閥 值で判別することが可能であることからも、NU I が緑被と非緑被の判別に

\begin{tabular}{|c|c|c|c|}
\hline 項目 & 観測日 & パス・ロウ・サブシーン & 備考 \\
\hline シーン1 & 1985 年 5 月 2 日 & $112,37, \mathrm{C}$ & \\
\hline シーン2 & 1986 年 5 月 12 日 & $113,37, \mathrm{D}$ & \\
\hline シーン3 & 1987 年 5 月 8 日 & $112,37, \mathrm{C}$ & \\
\hline シーン4 & 1989 年 4 月 27 日 & $112,37, \mathrm{C}$ & 雲あり \\
\hline シーン 5 & 1990 年 5 月 16 日 & $112,37, \mathrm{C}$ & 雲あり \\
\hline シーン6 & 1990 年9月 21 日 & $112,37, \mathrm{C}$ & \\
\hline シーン 7 & 1997 年 4 月 24 日 & $112,37, \mathrm{C}$ & \\
\hline
\end{tabular}
有効であることが分かる。

シーン1（1985 年 5 月）とシーン7（1997 年 4 月）の画像を元に緑被か ら非緑被へ変化した地域を抽出する。ただし、変化ピクセルの判断基淮は下 記のように設定する。

変化ピクセル：(NU I $\left.{ }_{97} \geqq 200 ） （ \mathrm{NUI}_{97-85} \geqq 50\right)$

\begin{tabular}{|c|c|c|c|c|c|}
\hline \multicolumn{6}{|c|}{ 表一 5} \\
\hline \multicolumn{2}{|c|}{ 土地被覆 } & BAND3 & BAND4 & BAND5 & BAND6 \\
\hline \multirow{3}{*}{ 緑 被 } & 樹 . 才 & 小 & 大 & 中 & 小 \\
\hline & 畑・草地 & 中 & 中 & 中 & 小 \\
\hline & 水 白 & 中 & 小 & 小 & 中 \\
\hline \multirow{2}{*}{ 非緑被 } & 市街地 & 大 & 小 & 中 & 大 \\
\hline & 裸 & 大 & 中 & 大 & 大 \\
\hline \multicolumn{2}{|c|}{ 水 面 } & 小 & 小 & 小 & 小 \\
\hline
\end{tabular}
非変化ピクセル : 上記以外
表一4 5章における使用データ

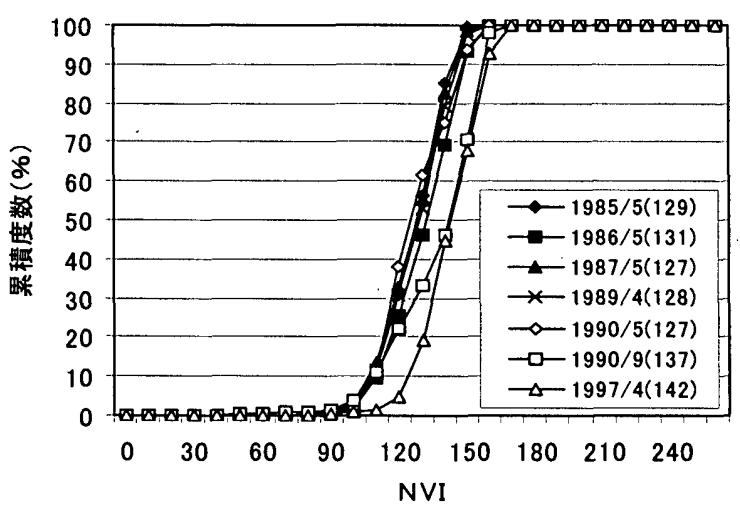

图ー7 各シーンにおけるNVIの累積度数分布（凡例カッコ内は平均値）

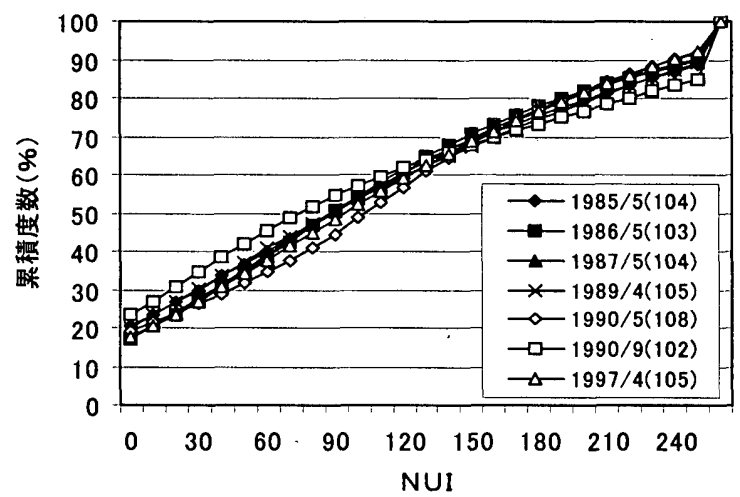

図ー8 各シーンにおけるNUIの累積度数分布（凡例カッコ内は平均値）

緑被加非緑被への変化地域を図一10 に示寸。また、図一11 は熊本市役 所を中心に 16 方位、 $2 \mathrm{~km}$ 間隔で変化率を算出した結果である。市南部及び 東部で変化地域が大きく、市中心部および北西の金峰山では変化がほとんど 見られない。近年、開発が進んだ南部の平成町、流通団地周辺では特に変化 率が高くなっており、現地調查においてもその状况か確認された。

\section{6. まとめ}

ランドサット TMデータを用いて土地被覆の経年変化を抽出する 場合に問題となる放射照度等や緑の生育具合の影響について検討し その除去方法について提案した。

本報告で明らかになった点を整理すると下記の通りである。

1)ランドサットTMの観測時に雲量が 0である頻度は $5 \%$ 程度で 

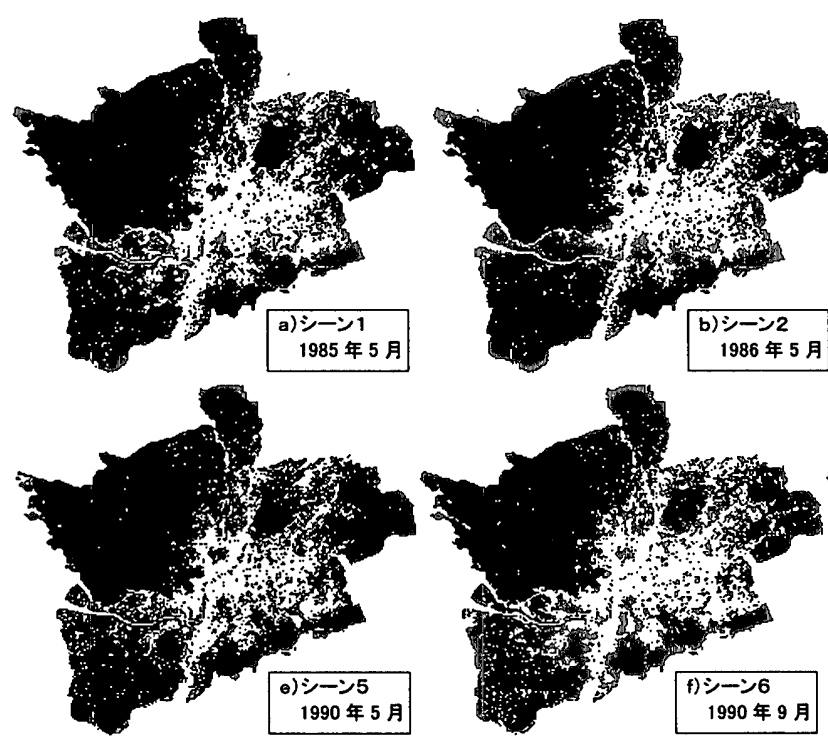

あり、土地被覆の経年変化の抽出を目的としてランドサットT

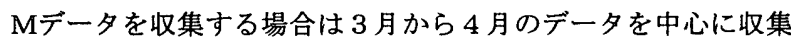
する方がデータ数が確保しやすい。

2)気象条件の違いによって生じる放射照度の影響は、度数分布よ り求めた 1 次式により概ね除去することが可能である。

3） N V I を用いて土地被覆変化を求める方法は、水田など季節に よる緑の生育具合の影響を受けるため、土地開発などの状況の 抽出が困難な場合がある。

4）本報告で提案したNU I は放射照度や緑の生育具合にあまり影 響されることがなく、緑被と非緑被の判別において異なる年度 及び季節のデータを用いてもほぼ同様の判別結果となる。

5) NUI は度数分布が均一で分散が大きいため緑被と非緑被の闇 值の設定が容易であり、各シーンに共通の閾值を 1 個設定する だけで緑被から非緑被への土地被覆の変化を求めることが可能 である。

6)熊本市における 1985 年から 1997 年の土地被覆変化の状況を N U I を用いて定量的に明らかにした。その結果、熊本市では市 の南部から東部にかけて緑被から非緑被へ変化しており、現地 調查で確認された土地開発の状況と一致した。

NU I は従来の土地被覆分類の結果を比較する方法に比べて計算 方法が簡単であり、また、教師の抽出など経験を必要とする作業も 行うことなく土地被覆の経年変化を求めることが可能である。しか し、その精度に関しては、まだ十分な評価をしておらず、今後さら に詳細な検討を進めるとともに、他の都市の経年変化や、都市同士 の比較についても適用可能であるか検討していく予定である。

\section{参考文献}

1) 渡辺浩文, 依田浩敏, 尾島俊雄 : リモートセンシングデータと数值情報利 用による広域都市の地表面温度分布図の作成に関する研究, 日本建築学会 計画系論文報告集，No. 443，pp. 21-29，1993.1

2)森山正和，鈴木和弘，官崎ひろ志 : ランドサットデータを用いた夏季の広 域的温熱罟境評価に関する研究, 日本建築学会計画系論文集，№. 482, pp. $51-56,1996.4$

3）宮崎ひろ志，㚞山正和：阪神・淡路大震災における地霞火災規模と緑被率， 建べ率等市街地特性との相関解析，日本建築学会計画系論文集，No. $520 ，$ pp. $77-81,1999.6$

4) 北澤秀吉, 高木直楖 : リモートセンシング画像のテクスチャを利用した市
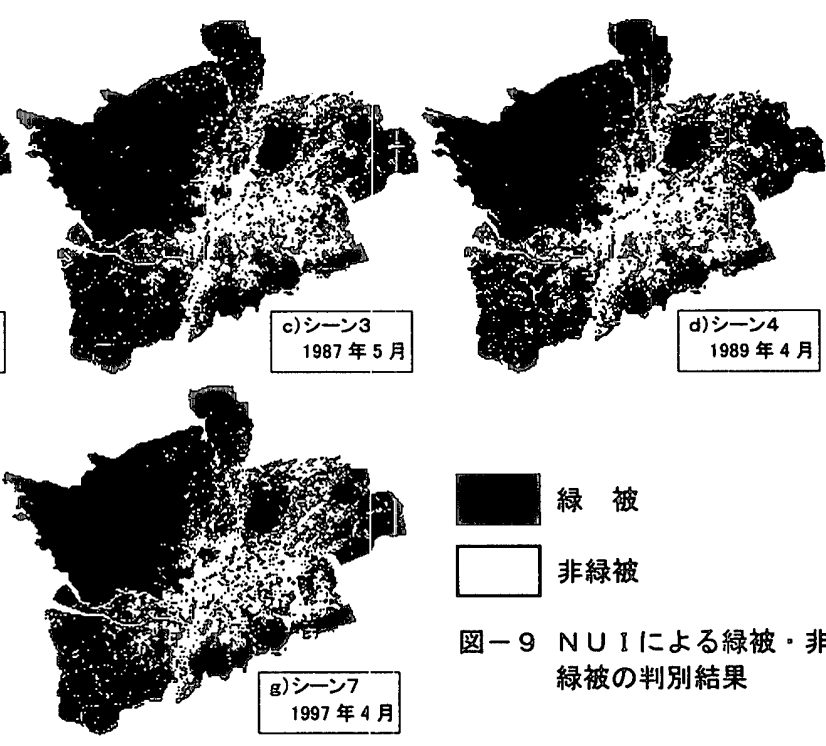

図ー9NUIによる緑被・非 緑被の判別結果
图－10 1985 年から $19: 97$ 年における緑被から非緑被への变化地域 の推定結果

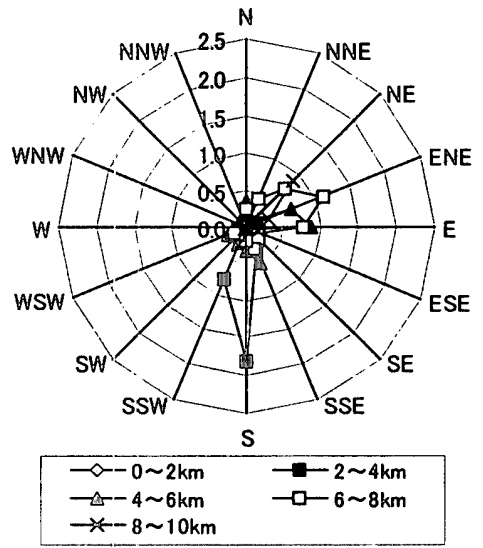

图ー11 1985 年から 1997 年における距離および方位別の緑被変化 の割合 (\%)

街地形態の推定，日本建筑学会大会学術講演梗概集，pp. 222-223，1999.9 5)婑山正和，竹林英樹 : 正規化植生指標（NVI）と一次元熱収支モデルに基つ いたクリマトープ図の作成手法に関する研究，日本建築学会計画系論文集， No. 518 , pp. $61-65, \quad 1999.4$

6) 宮崎ひろ志，森山正和 : 都市開発に伴う自然環境变化に関する研究一リモ 一トセンシング手法による緑被率変化の解析一, 第 16 回情報・システ ム・利用・技術シンポジウム論文集，pp. 277-281，1993. 12

7) 平野勇二郎 : 都市域における植生指標 NVI とその季節変化の土地利用形態 による特性，日本建築学会計画系論文集，No. 548，pp. 75-82，2001. 10

8)佐々波清夫，磯部邦昭，中山裕則：ランドサットデータによる関東平野中 央部の土地被覆変化, 日本リモートセンシング学会誌, pp. 35-44, 1988.3

9)大林成行編著 : 実務者のためのリモートセンシング, フジ・テクノシステ 厶, 1995.8 